\title{
17. METHANE IN CANNED CORE SAMPLES FROM SITE 262, TIMOR TROUGH
}

\author{
Richard D. McIver, Esso Production Research Company, Houston, Texas
}

At DSDP Site 262, cores from the top 300 meters of sediments appeared to be very gassy because they expanded by as much as a third in length when brought to the deck of the Glomar Challenger. Small portions of some cores from this obviously gassy section were sealed in cans, as done on previous legs, and these were shipped to us to determine the amount and nature of gas still remaining in the sample at the time of sampling. The quantity and conposition of the hydrocarbon portion of the gas, and the total organic carbon, were determined on nine of these samples by procedures reported earlier (McIver, 1973). Results of this study are summarized in Table 1 and Figures 1 and 2.

As the figures show, these Pleistocene-Holocene sediments are fairly gassy. They have above-average gas contents (Mclver, in press) - but about average for the group of samples in the richer of the two distributional modes_-and that gas is virtually all ( $>99.99 \%)$ methane. Furthermore, the samples have about as much gas per unit weight of organic carbon as many of the samples analyzed earlier from previous legs. The gas concentration is pretty uniform down the hole; the one exception may be due to difference in porosity or sample handling rather than any basic difference in organic matter or in situ concentration of gas (McIver, 1973).
The organic-carbon contents are above average for DSDP samples, in general, and they can be interpreted to have considerable potential to generate liquid and/or gaseous hydrocarbons should they be buried more deeply (subjected to higher temperatures) for long enough periods geologically to begin the thermal cracking process.

\section{ACKNOWLEDGMENTS}

This work would not have been possible without the assistance of Ralph Pokluda, Harvey Fry, and Charles Huang, and the continuing support of Esso Production Research Company with whose permission this report is submitted.

\section{REFERENCES}

Mclver, R.D., 1973. Hydrocarbon gases from canned core samples, Sites 174A, 176, and 180. In Kulm, L.D. van Huene, R., et al., Initial Reports of the Deep Sea Drilling Project, Volume 18: Washington (U.S. Government Printing Office)p. 1013

McIver, R.D., in press. Gaseous and heavy hydrocarbons in canned core samples from Leg 24, DSDP. In Fisher, R.L., Bunce, E.T., et al., Initial Reports of the Deep Sea Drilling Project, Volume 24:Washington (U.S. Government Printing Office).

TABLE 1

Site 262 Samples (Water Depth, $2315 \mathrm{~m}$ )

\begin{tabular}{cccccc}
\hline & Section & $\begin{array}{c}\text { Depth } \\
\text { in Core } \\
(\mathrm{cm})\end{array}$ & $\begin{array}{c}\text { Approx. Depth } \\
\text { Below Mudline } \\
(\mathrm{m})\end{array}$ & $\begin{array}{r}\text { Organic } \\
\text { Carbon } \\
\text { Content } \\
\text { (Wt. \%) }\end{array}$ & $\begin{array}{c}\text { Hydrocarbon } \\
\text { Gas Content } \\
\text { (ppm) }\end{array}$ \\
\hline 12 & CC & - & 110 & 0.77 & 66,800 \\
13 & 3 & 0 & 113 & 1.04 & 53,300 \\
13 & 3 & 150 & 113 & 0.71 & 37,000 \\
13 & 4 & 0 & 114 & 0.78 & 31.800 \\
13 & 4 & 150 & 114 & 0.89 & 43,700 \\
13 & 5 & 0 & 116 & 0.93 & 45,200 \\
14 & 4 & 0 & 124 & 0.48 & 97,100 \\
17 & 1 & $?$ & 148 & 0.93 & 8,300 \\
27 & 5 & 0 & 250 & 0.60 & 68,800 \\
31 & 2 & $?$ & 282 & 0.48 & 33,400 \\
31 & 3 & 0 & 284 & 0.50 & 68,700 \\
\hline
\end{tabular}

${ }^{a} 99.9+\%$ methane. 


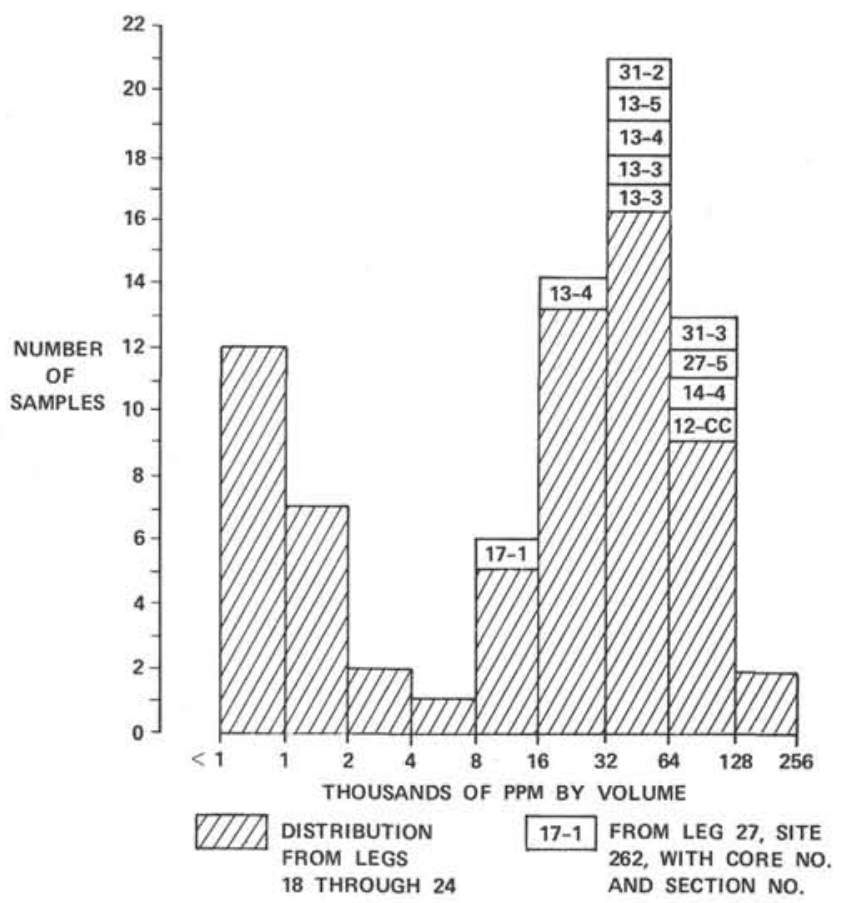

Figure 1. Range of residual gas contents of Leg 27 canned muds compared with previous results.

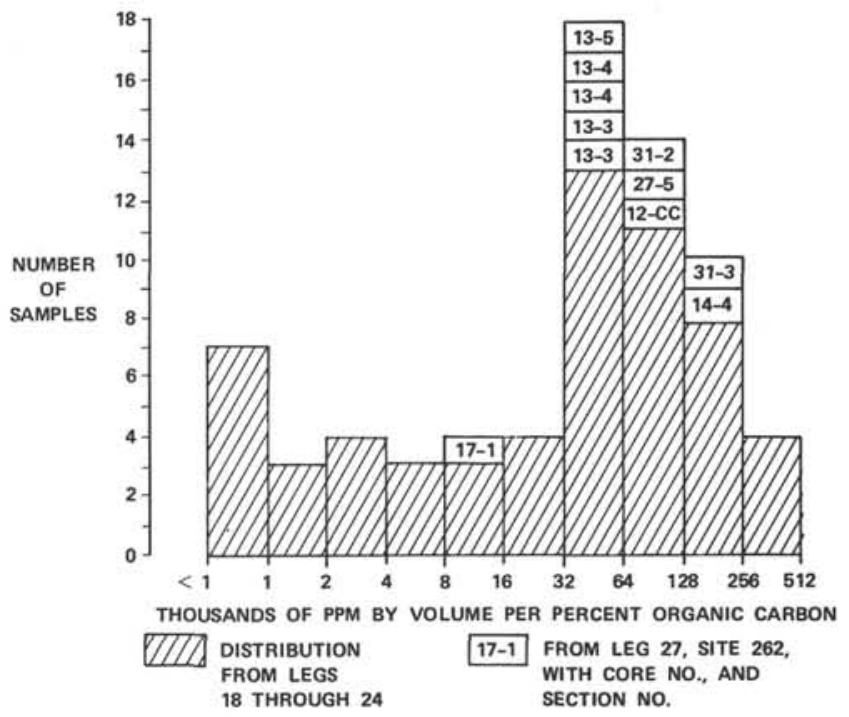

Figure 2. Ratios of gas contents to organic carbon of Leg 27 canned muds compared with previous results. 